budget reductions, according to the press release, employees in both Ottawa and Petawawa will have to be laid off. About 50 employees of the two institutes in Ottawa are expected to be released as well as about 18 from P.F.E.S., almost $1 / 4$ of the staff. The staff at P.F.E.S. did not receive a telephone message this time, but heard it over the media.

There has been one more event in the story of P.F.E.S. to the time of writing. A rally, organized by "Forests for the Future" was held on the Station on November 5. About 200 people were in attendance, including a large contingent from Ottawa and representatives from the major political parties. Although congratulations were expressed by many to those who helped keep P.F.E.S. open, dissatisfaction was very much in evidence - dissatisfaction with the decline in forestry research in particular and with government policy in general. Liberal MP Len Hopkins, Don Munro, the Progressive Conservative Environment Critic and MP Cyril Symes (NDP, Sault Ste. Marie) had to field many questions on these topics.

A. D. Hall, Executive Director of the Canadian Forestry Association, congratulated the people of the Upper Ottawa Valley for their effort to keep P.F.E.S. He called it the "finest expression of citizenship" we've had in forestry in a long time. He said the proposed reduction has focused attention on the forestry industry nationally and this attention is good.

Professor Paul L. Aird, University of Toronto, in his address to the rally described Petawawa as a "symbol of concern for the future", but criticized the Government for its lack of political will to care and to plan for the future of Canada. "Our trust in the federal government and its plans for the future were shattered with the recent announcement of plans to close P.F.E.S. In the past, the politicians and bureaucrats have found it easy to cut down support for the trees. In the last dozen years, they reduced the federal forest research effort to one half of its former status with little public outcry". Closing an entire Station was a major jolt, however, said Prof. Aird. He suggested that the decision was made by people who did not appreciate the Station's worth and did not anticipate the public outcry. He pointed out that the Minister has not visited P.F.E.S., nor the Deputy Minister, nor the Senior Assistant Deputy Minister, nor the Assistant Deputy Minister and so on. "Closing P.F.E.S. has symbolized the lack of political will to care and to plan for the future of Canada", stated Prof. Aird. His statement that what this nation needs is someone "to take Government, to take Cabinet and to shake it until the beast thinks green" met with enthusiastic applause from the audience. He called for Petawawa to be used "as a symbol to kindle a national reawakening of man's dependence on living nature and to stimulate a national willingness to maintain our biological resource base for all time".

In his speech to the Vancouver Section last December, Environment Minister Len Marchand told foresters that they will have to take their cause into the political arena if they want to see action on improved forest management. He said, "You have to get involved with the political process and make it work for you. A unified forestry constituency in Canada would, frankly, carry a lot of political clout. Get your hands on that clout and use it for the betterment of the forest resource and our economy - and for the people of Canada". $\mathrm{He}$ was absolutely right. The decision to close P.F.E.S. was purely political. It was political activity that changed that decision. The new decision, which still effectively reduces the Canadian Forestry Service, is in reality a political smoke screen. The story of P.F.E.S. should be a lesson to everyone concerned about forestry in Canada. Get together and get political!

B. D. Haddon

\section{Excerpts from the Honourable Len Marchand's Keynote Speech to the CIF-SAF Meeting}

- The theme of this meeting is "North American Forests: Gateway to Opportunity". It is, I think, an apt theme for several reasons. Canada and the United States are as one when it comes to forests. All of us here today are brought together because of a common interest: utilizing the North American forest resource to its best possible advantage.

- Throughout history, however, there have been those who recognized the forests as the living treasure they are. It is, in large part, because of people like these - people like all of you here today - that our two countries enjoy the large and diversified economies we now possess. Industrial giants that we are, there are still wooden shoes upon our feet.

- Our progress must be won through greater efficiency in terms of our exploitation of the forest resource. We must balance our wishes for greater yields from forestry with environmental realities which not only take into account our moments on the planet but those of all future generations. We can have more from our forests only if we proceed with prudence.

- To turn this objective into reality, there is a role to be played by all concerned parties - the forester, the politician, the industry and the public. There must be recognition among these people that their roles, although closely related, are not identical. I charge you - the foresters of North America - with the key catalytic role. You 
are the ones who must take the lead in the enlightenment of the public, and I suggest to you, because I have some knowledge in this area, that the politician reacts quickly and positively to a concerned and knowledgeable public. It is not enough that every forester in North America knows what is needed; the public must know too. Without public support, little will be accomplished.

- With the exception of forest spraying, it has been decades since forestry in Canada has been a hot political issue in any region or on a national scale. Frankly, I am astonished by this. I've seen figures recently which indicate there may be as much as 70 million acres of prime forest land in Canada that is not adequately regenerated. And worse, the backlog grows annually. In a nation so dependent upon its forest-based industry for economic survival, this is unthinkable. But, even to this day, there has been little or no public outcry for better forest management.

- For decades there have been calls for a national forest policy in Canada. But, aside from the expressed views and positions of various individuals, there has been little activity at the political level. The fact remains: we need a national forest policy in Canada.

- All of us here today are aware of the dramatically and rapidly changing economic and social conditions. The days of unlimited resources are quickly drawing to a close. We have now a fertile climate for serious discussions on a national forest policy.

- Although the forest resource will not singlehandedly solve the energy problems we face, it is worth keeping in mind that no other single solution will either. There needs to be an attack on all facets of the energy situation: total consumption must be reduced, greater efficiency in all conversions must be achieved, and all renewable sources of energy must be given a close look.

- As Minister of the Environment, charged with both resource management and environment protection, I see, daily, the need for a balanced approach to our resources. We can no longer lock the door on any portion of our natural wealth nor can we permit uncontrolled resource exploitation. What we must achieve is a balanced settlement of conflicts whereby we can wisely manage our renewable resources for many purposes without impairing their productivity.

\title{
KALEIDOSCOPE
}

\section{Thank Yow}

\author{
The Petawawa Forest Expreriment Station \\ remains open loday primaxily because of \\ suppont from onganizations and individuals \\ locally, across Canada, \\ and indeed throughout the woold. \\ The sum total of this suppont was mone \\ than we even imagined possible. \\ We ane deeply grateful for youx contribution. \\ Shaff of the Pelaurausa Foned \\ Exxheriment Station
}

